\title{
Фотоэлектрические и оптические свойства многослойных структур с использованием por-Si, изготовленным по различным технологическим маршрутам
}

\author{
И.А. Шишкин, Д.А. Лизункова \\ Самарский национальный исследовательский университет им. академика С.П. Королева, \\ 2. Самара, 443086, Московское шоссе, 34 \\ тел:+7 (902) 153-5911, эл. почта: shishkinivan9@ gmail.ru
}

DOI 10.34077/RCSP2019-133

В настоящее время перспективными солнечными элементами являются многослойные структуры, которые широко используются в космической и промышленной отрасли. Пористый кремний используется в фоточувствительных образцах в качестве рабочего слоя, который позволяет увеличить генерацию неосновных носителей заряда и повысить её эффективность [1].

Определение основных фотоэлектрических параметров выполнялось на подложках монокристаллического кремния с различным типом обработки поверхности (текстурированная, шлифованная). Получение пористого кремния производилось электролитическим травлением в растворе $\left(H F: C_{2} H_{5} O H\right)$ в пропорции 1:1 при использовании однокамерных ячеек вертикального и горизонтального типа. Однако формирование $\mathrm{p}-\mathrm{n}$ перехода осуществлялось для двух типов образцов в разных рабочих слоях, а именно в первом случае диффузия фосфором и бором создавалась посредством нанесения пленок фосфорного и борного диффузантов на подложке кремния для сторон $\mathrm{n}$ - типа и $\mathrm{p}$ - типа соответственно. Во втором случае данный процесс проводился непосредственно в пористый кремний. Процесс диффузии для стороны $\mathrm{p}-$ типа проходил 30 минут при температуре $1000 \pm 5{ }^{\circ} \mathrm{C}$, а для стороны $\mathrm{n}$ - типа проходил 40 минут при температуре $850 \pm 5{ }^{\circ} \mathrm{C}$. Глубина залегания $\mathrm{p}-\mathrm{n}$ перехода для двух разных рабочих слоев составляла порядка 3 мкм. После всех процедур осуществлялось удаление фосфорносиликатного и боросиликатного стекол в фтороводородной кислоте. Далее на n-слое кремния создавались алюминиевые контакты и просветляющее покрытие сульфида цинка путем термического испарения в вакууме.

Во втором случае при проведении операции диффузии примеси в пористый слой существует риск повредить его нанокристаллическую структуру. Экспериментально было показано в работе [2], что для нанокристаллов кремния диаметром $5 \mathrm{~nm}$ температура плавления падает до 900 градусов. Эффект снижения точки плавления наблюдался также для пористого кремния (por-Si), который содержит нано- и микрокристаллы размером от единиц нанометров до десятков микрон.

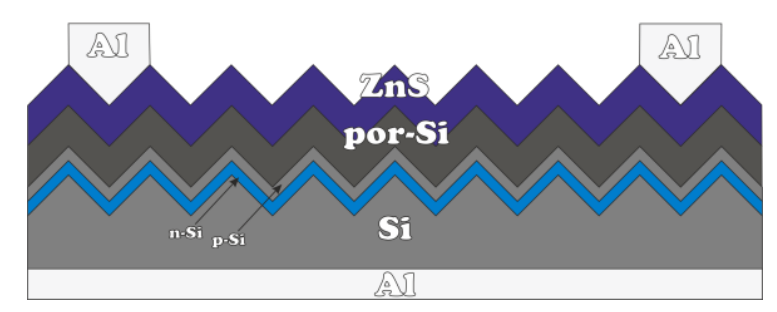

Рис.1. Схематичное изображение структур текстурированной поверхности.

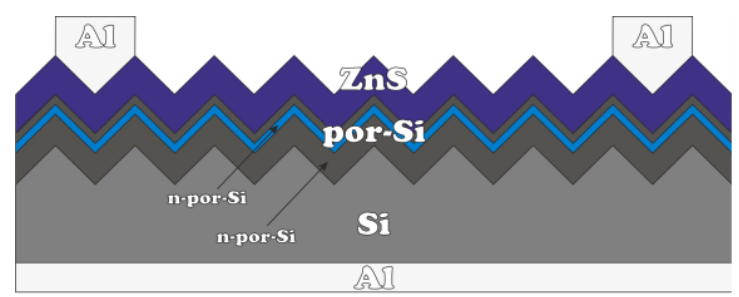

с разным расположением $\mathrm{p}-\mathrm{n}$ перехода на

Исследование спектральных и электрических свойств показало, что фотоэлектрические характеристики заметно выше у тех структур, в которых диффузия проходила в подложку кремния (рис.1a).

\section{Лuтература}

[1] Н.В .Латухина, Т.С. Дереглазова, С.В. Ивков, А.В. Волков, В.А. Деева Фотоэлектрические свойства структур с микро- и нано-пористым кремнием // Известия Самарского научного центра PAH. 2009. - T. 11. № 3 (29). С. 66 - 7.

[2] YangC.C. atel.// J. of Physics C: Condensed Matt. 2003. Vol.15. N 29.P.4961-4965 